\title{
Ganoderma lucidum exerts anti-tumor effects on ovarian cancer cells and enhances their sensitivity to cisplatin
}

\author{
SUFEN ZHAO ${ }^{1,2}$, GANG YE $^{1}$, GUODONG FU $^{1}$, JIAN-XIN CHENG ${ }^{3}$, BURTON B. YANG $^{4}$ and CHUN PENG $^{1}$ \\ ${ }^{1}$ Department of Biology, York University, Toronto, Canada; \\ ${ }^{2}$ Department of Obstetrics and Gynecology, The Second Hospital of Hebei Medical University; \\ ${ }^{3}$ Department of Obstetrics and Gynecology, The Fourth Hospital of Hebei Medical University, Shijiazhuang, \\ P.R. China; ${ }^{4}$ Sunnybrook Research Institute, Sunnybrook Health Sciences Centre, Toronto, Canada
}

Received December 7, 2010; Accepted January 10, 2011

DOI: 10.3892/ijo.2011.965

\begin{abstract}
Ganoderma lucidum is a herbal mushroom known to have many health benefits, including the inhibition of tumor cell growth. However, the effect of Ganoderma lucidum on epithelial ovarian cancer (EOC), the most fatal gynecological malignancy, has not yet been reported. In this study, we determined whether Ganoderma lucidum regulates EOC cell activity. Using several cell lines derived from EOC, we found that Ganoderma lucidum strongly decreased cell numbers in a dose-dependent manner. Ganoderma lucidum also inhibited colony formation, cell migration and spheroid formation. In particular, Ganoderma lucidum was effective in inhibiting cell growth in both chemosensitive and chemoresistant cells and the treatment with Ganoderma lucidum significantly enhanced the effect of cisplatin on EOC cells. Furthermore, Ganoderma lucidum induced cell cycle arrest at the G2/M phase and also induced apoptosis by activating caspase 3 . Finally, Ganoderma lucidum increased p53 but inhibited Akt expression. Taken together, these findings suggest that Ganoderma lucidum exerts multiple anti-tumor effects on ovarian cancer cells and can enhance the sensitivity of EOC cells to cisplatin.
\end{abstract}

\section{Introduction}

Ganoderma lucidum is a herbal mushroom that has been widely used in preventive medicines in China and other Asian countries for over 2,000 years. It has also become a popular dietary supplement in Western countries. Ganoderma lucidum contains many different bioactive compounds, which mainly include triterpenoids, polysaccharides, nucleotides, sterols, steroids, fatty acids, proteins/peptides and trace elements (1).

Correspondence to: Dr Chun Peng, Department of Biology, York University, 4700 Keel Street, Toronto, ON M3J 1P3, Canada

E-mail: cpeng@yorku.ca

Key words: Ganoderma, ovarian cancer, chemoresistant cells
These substances are known to have many biological activities, including anti-tumor (2), immunomodulatory (3), anti-viral (4), anti-hepatitis (5), antioxidant (6), antihypertensive $(7,8)$ and anti-diabetic activities (9). It has been reported that Ganoderma lucidum extracts can inhibit tumor formation and the proliferation of breast and prostate cancer, hepatoma, melanoma lymphoma and myeloid leukemia cell lines (10-12). Thus, Ganoderma lucidum could be used as a potential therapeutic agent in the form of a dietary supplement for cancer patients.

Epithelial ovarian cancer (EOC) is the most common form of ovarian cancer and the leading cause of death from gynecological disorders (13). The high mortality rate of EOC is mainly due to the late diagnosis and the lack of effective treatments for the late stages of the disease (14). The most effective treatment for EOC is surgery plus platinum-based chemotherapy, with drugs such as cisplatin. However, the majority of patients ultimately experience chemoresistance and recurrence of their disease (15). Considering the high mortality rate of ovarian cancer due to the absence of effective treatment in advanced stages or during relapse, new therapeutic strategies are urgently required.

In this study, we examined the effects of Ganoderma lucidum on cell proliferation and migration in several ovarian cancer cell lines. Our results show that Ganoderma lucidum inhibits cell growth, migration and spheroid formation in both chemosensitive and chemoresistant ovarian cancer cells. Ganoderma lucidum also induced cellular apoptosis by down-regulating anti-apoptotic proteins. Ganoderma lucidum greatly enhanced the sensitivity of chemoresistant cells to cisplatin, possibly by up-regulating p53 and down-regulating Akt.

\section{Materials and methods}

Cell culture. The immortalized human ovarian surface epithelial cell line, IOSE-398, and the EOC cell lines, OV2008, C13*, A2780s and A2780-cp, were obtained and cultured as described previously (16-18). Skov3 cells were obtained from ATCC and cultured in McCoy 5A medium containing $10 \%$ FBS and $1 \%$ penicillin/streptomycin. Cells were grown at $37^{\circ} \mathrm{C}$ in an atmosphere with $5 \% \mathrm{CO}_{2}$. 
Preparation of Ganoderma lucidum. The Ganoderma lucidum used in this study is a mixture containing sporoderm-broken spores by enzymatic methods and polysaccharides extracted from fruiting bodies, as previously described (19). A stock solution of $50 \mathrm{mg} / \mathrm{ml}$ was prepared by adding water and then boiling for $5 \mathrm{~min}$. After a brief centrifugation, the supernatant was collected and passed through a $0.2 \mu \mathrm{m}$ filter. The stock solution was stored at $4^{\circ} \mathrm{C}$.

Cell proliferation and viability assays. Cell proliferation and viability were determined using manual counting and WST-1 assays. For manual counting, cells were seeded in 24-well plates. After treatment with Ganoderma lucidum, cells were fixed with methanol containing $1 \mu \mathrm{g} / \mathrm{ml}$ DAPI. The DAPIstained cells were viewed at X100 magnification under a fluorescent microscope (Nikon Eclipse TE 2000-U). Five randomly selected fields in each sample were photographed, scored and averaged for cell numbers. For WST-1 assay, cells were seeded on 96-well culture plates at a density of 10,000 cells per well and cultured for $24 \mathrm{~h}$ prior to treatment. After treatment with different concentrations of Ganoderma for $48 \mathrm{~h}$, WST-1 reagent was added to the cells and absorbance was measured at $450 \mathrm{~nm}$ using an ELISA plate reader.

Treatment with cisplatin. The cells were cultured in 24-well plates at a density of $6 \times 10^{4}$ cells per well and treated with $0.5 \mathrm{mg} / \mathrm{ml}$ Ganoderma lucidum and different concentrations of cisplatin for $48 \mathrm{~h}$. At the end of the experiment, live cell numbers were counted as described above.

Cell cycle analysis. To determine the cell cycle profile following Ganoderma treatment, flow cytometry was performed. Briefly, $2 \times 10^{6}$ cells were collected, washed twice with PBS, and fixed with $3 \mathrm{ml}$ ice-cold $70 \%$ ethanol. The cells were then washed twice with cold PBS, resuspended with $1 \mathrm{ml}$ staining buffer containing $50 \mu \mathrm{g} / \mathrm{ml}$ RNase A and stained with $50 \mu \mathrm{g} / \mathrm{ml}$ propidium iodide for $1 \mathrm{~h}$ at room temperature in the dark. Finally, samples were analyzed by flow cytometry using FACScalibur (BD Biosciences, San Jose, CA, USA).

Hanging drop culture for spheroid formation. Skov3 cells were cultured in McCoy 5A medium containing $10 \%$ FBS and $1 \%$ penicillin/streptomycin. Cells were then trypsinized, resuspended in the same culture medium, and treated with different doses of Ganoderma lucidum $(0.5,1,2 \mathrm{mg} / \mathrm{ml})$. Hanging drop culture was performed using a method previously described for ovarian cancer cells (20) with slight modifications. Briefly, $15 \mu \mathrm{l}$ droplets, each containing 10,000 cells, were seeded on the inner surface of a Petri dish cover. The covers were then inverted and placed on a dish containing $15 \mathrm{ml}$ of PBS. The formation of spheroids was examined and photographed on the fourth day after the plating of the droplets.

Assessment of apoptosis by Hoechst 33258. Apoptotic cells were identified morphologically by Hoechst 33258 DNA staining (Sigma, Oakville, ON, Canada). Briefly, cells were cultured on $6-\mathrm{cm}$ dishes at $5 \times 10^{4}$ cells/dish and treated with $1 \mathrm{mg} / \mathrm{ml}$ Ganoderma lucidum for $48 \mathrm{~h}$. At the end of the experiment, the cells were fixed in $4 \%$ paraformaldehyde at room temperature for $20 \mathrm{~min}$, and then incubated with $1 \mu \mathrm{g} / \mathrm{ml}$ Hoechst 33258 for 15 min. After washing with PBS, cells were assessed for typical apoptotic nuclear morphology (nuclear shrinkage, condensation and fragmentation) using a fluorescent microscope (Nikon Eclipse TE 2000-U).

Western blot analysis. The protein lysates were separated in $12 \%$ SDS polyacrylamide gels, transferred to Immobilon PVDF Membranes (Millipore, Toronto, ON, Canada), and probed with anti-Bcl-2, Bcl- $x_{L}$, cleaved caspase 3, Akt, phosphor-Akt (1:1000 dilution, Cell Signaling, Danvers, MA, USA) and anti-p53 antibodies (1:1000, Santa Cruz Biotechnology, Santa Cruz, CA, USA). The ECL kit (GE Healthcare, Baie d'Urfe, Quebec, Canada) was used for the chemiluminescent detection of immobilized proteins. Protein loading was evaluated using mouse anti- $\beta$-actin (Sigma).

Wound healing assay. OV2008 and C13* cells were cultured in 6-well plates until cells reached near confluence and a wound was made using a $200 \mu \mathrm{l}$ pipette tip. After scratching, the culture medium was refreshed and different doses of Ganoderma lucidum $(0,0.5,1,2 \mathrm{mg} / \mathrm{ml})$ were added. Ten points were marked randomly down the wound and photographs were taken at the same points before and $24 \mathrm{~h}$ after incubation with Ganoderma lucidum. The area migrated by the cells was measured by computer Simple PCI software (Compix Inc., Cranberry Township, PA, USA).

Cell clonogenic assay. Clonogenic assay was performed according to a previously described protocol (21) with a slight modification. Briefly, Skov3 cells were seeded onto $60-\mathrm{mm}$ culture dishes at a density of $5 \times 10^{3}$ cells/well in McCoy $5 \mathrm{~A}$ complete culture medium in a humidified $37^{\circ} \mathrm{C}, 5 \% \mathrm{CO}_{2}$ incubator. Following cellular attachment, different concentrations of Ganoderma lucidum were added to the culture medium. Cultures were maintained for 7 days until the visible clones appeared. The colonies were fixed with $4 \%$ paraformaldehyde and stained with $0.5 \%$ crystal violet. The plates were then photographed.

Statistical analysis. The data were expressed as the means \pm SEM. Statistical significance was determined using one-way analysis of variance and the Student-Newman-Keuls test for multiple group comparison. The Student's t-test was used for comparison between two groups. Statistical significance was defined as a value of $\mathrm{p}<0.05$.

\section{Results}

Ganoderma lucidum inhibits cell growth and viability in ovarian cancer cells. To determine the effect of Ganoderma on ovarian cancer cells, we first treated cells with $0.1,0.5$ and $1 \mathrm{mg} / \mathrm{ml}$ of Ganoderma. The immortalized ovarian epithelial cell line, IOSE-398, and two pairs of ovarian cancer cell lines, A2780-s (chemosensitive)/A2780-cp (chemoresistant) and OV2008 (chemosensitive)/C13* (chemoresistant), were used. As shown in Fig. 1A, with the exception of IOSE-398 cells, all other cell lines showed a decrease in the number of cells after treatment with higher doses of Ganoderma. A significant effect on cell growth was observed at $1 \mathrm{mg} / \mathrm{ml}$ Ganoderma 
A.

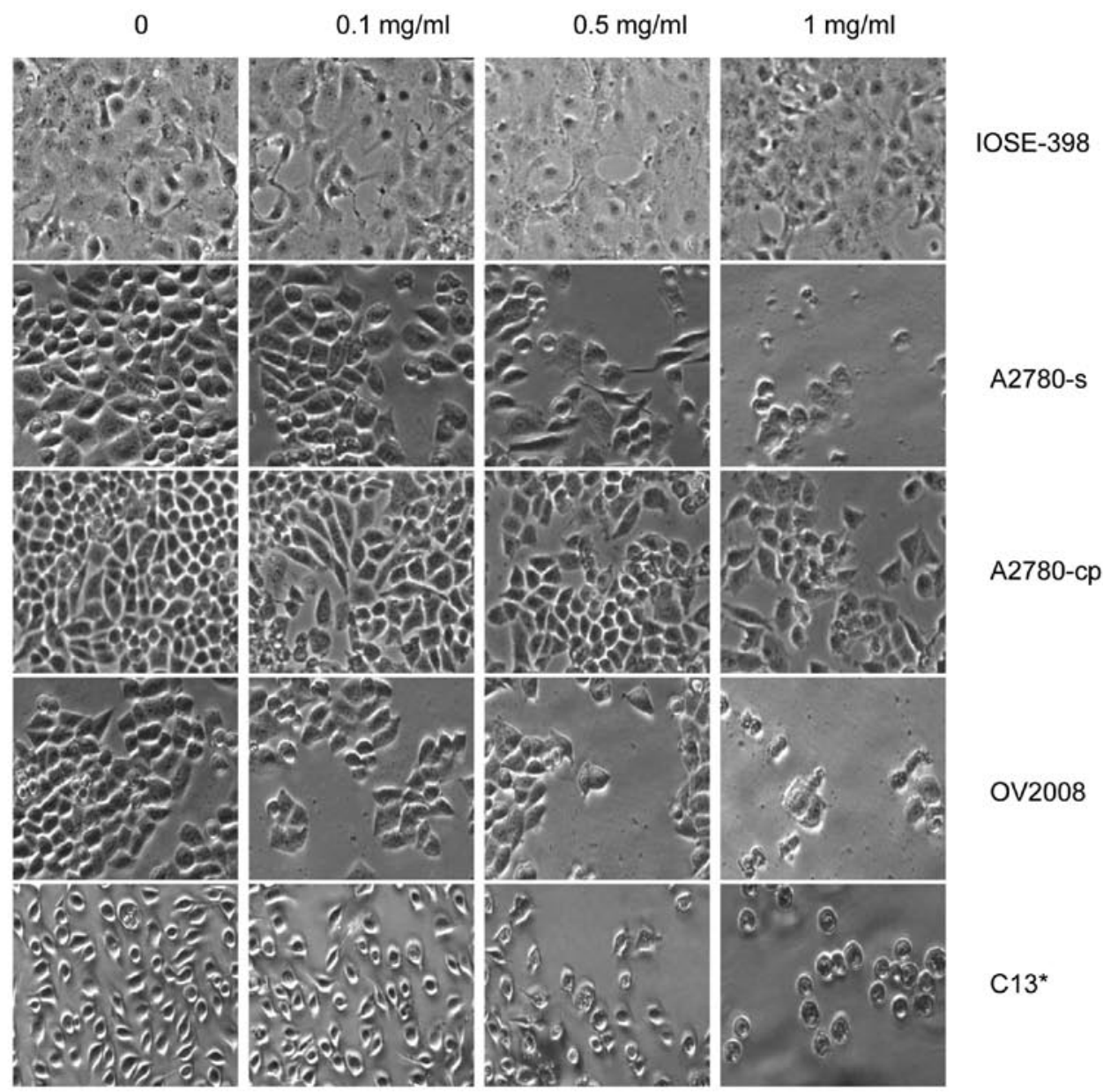

B.

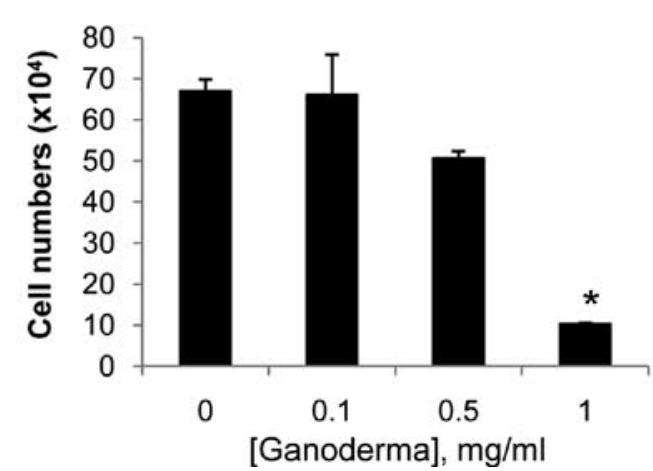

$\mathrm{C} 13^{*}$

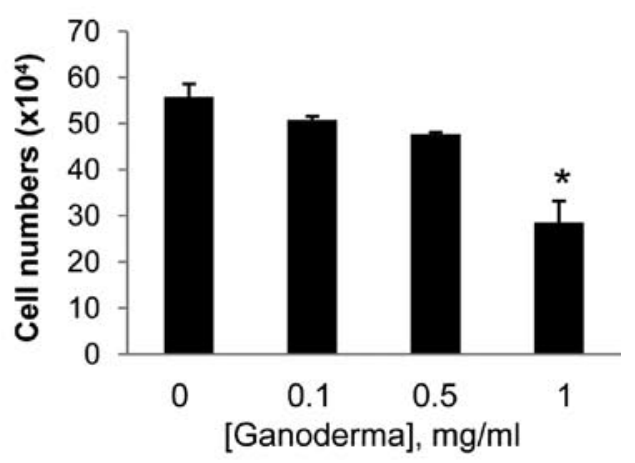

Figure 1. Ganoderma lucidum inhibited ovarian cancer cell growth. (A) Morphology of cells treated with different doses of Ganoderma. Photographs were taken at $48 \mathrm{~h}$ after treatment. (B) Cell numbers in the control and Ganoderma-treated groups. The OV2008 cell line and its chemoresistant countpart, the C13* cell line, were treated with Ganoderma for $48 \mathrm{~h}$. Cells were then fixed, stained with DAPI and counted. Data represent the means \pm SEM ( $=4$ ). ${ }^{*}<0.05$ vs. other groups.

(Fig. 1B). In order to confirm these results, WST-1 assays were performed and we observed that IOSE-398 cells were not affected by Ganoderma until cells were treated with a very high dose $(5 \mathrm{mg} / \mathrm{ml})$ for $48 \mathrm{~h}$. In contrast, OV2008 cells treated with 2.5 and $5 \mathrm{mg} / \mathrm{ml}$ of Ganoderma exhibited a very significant decrease in cell viability at 24 and $48 \mathrm{~h}$ after treatment (Fig. 2A). In 2780-s and 2780-cp cells, treatment with Ganoderma reduced cell viability, with the maximal effect observed at $1 \mathrm{mg} / \mathrm{ml}$ (Fig. 2B).

Ganoderma enhances the effect of cisplatin on ovarian cancer cells. As we observed that Ganoderma was effective in inhibiting growth/viability in both chemosensitive and chemoresistant cells, we examined whether it could enhance the 
A.

IOSE-398

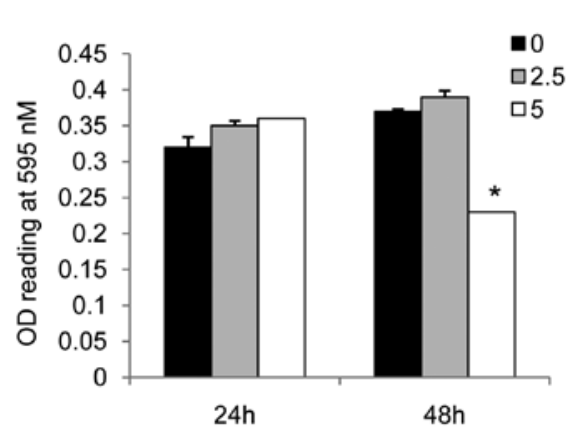

B.
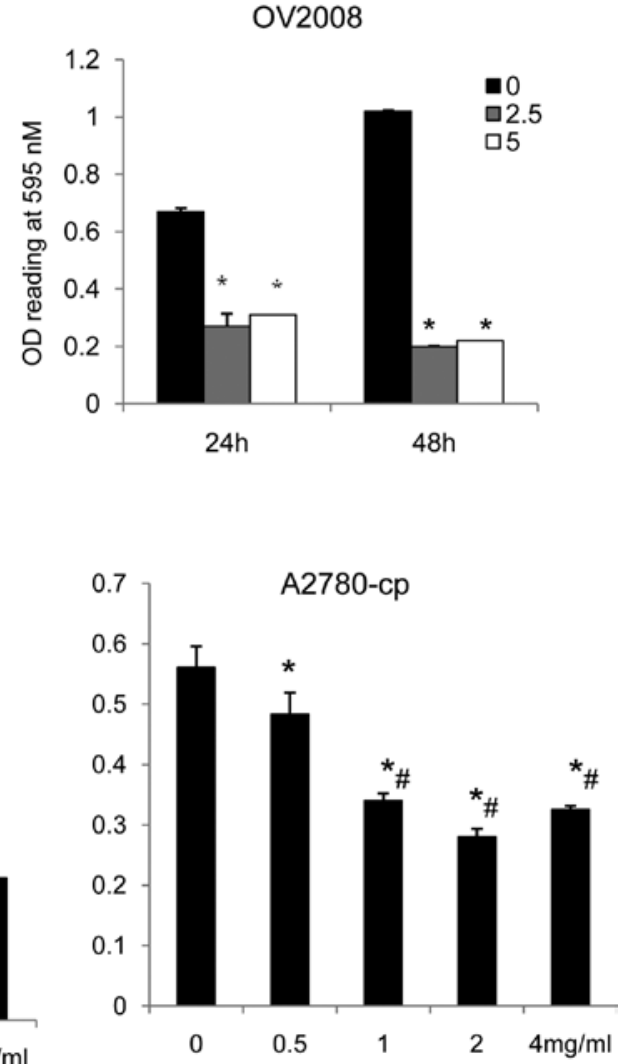

Figure 2. Ganoderma reduces the cell viability as measured by WST-1 assays. (A) IOSE-398 and OV2008 cells were treated with 0, 2.5 and 5 mg/ml of Ganoderma for 24 and 48 h. * $\mathrm{P}<0.05$ vs. the untreated control. (B) A2780-s and A2780-cp cells were treated with or without Ganoderma for 24 h. Data represent the means $\pm \operatorname{SEM}(\mathrm{n}=6) .{ }^{*} \mathrm{P}<0.05$ vs. the untreated control. ${ }^{\sharp} \mathrm{P}<0.05$ vs. $0.5 \mathrm{mg} / \mathrm{ml}$ treatment.

sensitivity of ovarian cancer cells to the chemotherapeutic agent, cisplatin. A2780-s and A2780-cp cells were treated with different concentrations of cisplatin in the presence or absence of a low dose of Ganoderma. The Ganoderma treatment alone slightly decreased the cell numbers. However, in the co-treatment with cisplatin, it significantly enhanced the effect of cisplatin on cellular growth inhibition (Fig. 3). We repeated these experiments using OV2008 and C13* cells and obtained similar results (data not shown).

Ganoderma inhibits cell migration and spheroid and colony formation. As Ganoderma inhibited cellular growth and viability in ovarian cancer cells, we hypothesized that it could have anti-tumor effects. To test this hypothesis, several experiments were performed. Firstly, OV2008 and C13* cells were treated without or with different doses of Ganoderma and a wound healing assay was carried out to determine whether Ganoderma affects cell migration. As shown in Fig. 4A, Ganoderma strongly inhibited wound closure in both cell lines. Secondly, the effect of Ganoderma on spheroid formation was assessed using a hanging drop culture. Skov3 is an invasive ovarian cancer cell line. When droplets of these cells were plated on the inner cover of a culture dish, the cells proliferated, aggregated and formed tight spheroids. However, in the cells treated with 1 and $2 \mathrm{mg} / \mathrm{ml}$ Ganoderma, only loose and irregular spheroids were observed (Fig. 4B). Finally, clonogenic assays were used to test the effect of Ganoderma on cell colony growth. Skov3 cells were treated with or without Ganoderma and plated. At 7 days after plating, colonies were stained and photographed. Ganoderma strongly inhibited colony formation in a dose-dependent manner (Fig. 4C).

Ganoderma induces apoptosis and blocks cell cycle progression at the G2/M phase. To examine how Ganoderma inhibited cell growth and viability, we used flow cytometry to determine the effect of Ganoderma on cell cycle progression. Analysis of the cell cycle profile in control and Ganoderma-treated cells revealed that Ganoderma increased the population of cells at the G2/M phase. It did not change the percentage of cells at the $\mathrm{S}$ phase but decreased the number of cells at the G1 phase (Fig. 5). We then determined whether Ganoderma regulates apoptosis. Hoechst staining showed that there were more cells showing features of apoptotic nuclei in the Ganoderma-treated cells. Using Western blot analysis, we found that Ganoderma inhibited the expression of the antiapoptotic proteins, $\mathrm{Bcl}-2$ and $\mathrm{Bcl}-\mathrm{x}_{\mathrm{L}}$, and increased the level of activated caspase 3 (Fig. 6).

Ganoderma induces p53 activation and inhibits Akt. Two molecules, p53 and Akt, have been reported to be involved in chemoresistance in ovarian cancer cells (22). To understand the mechanisms underlying the chemoenhancing effect of Ganoderma, we tested whether it could regulate p53 and Akt 

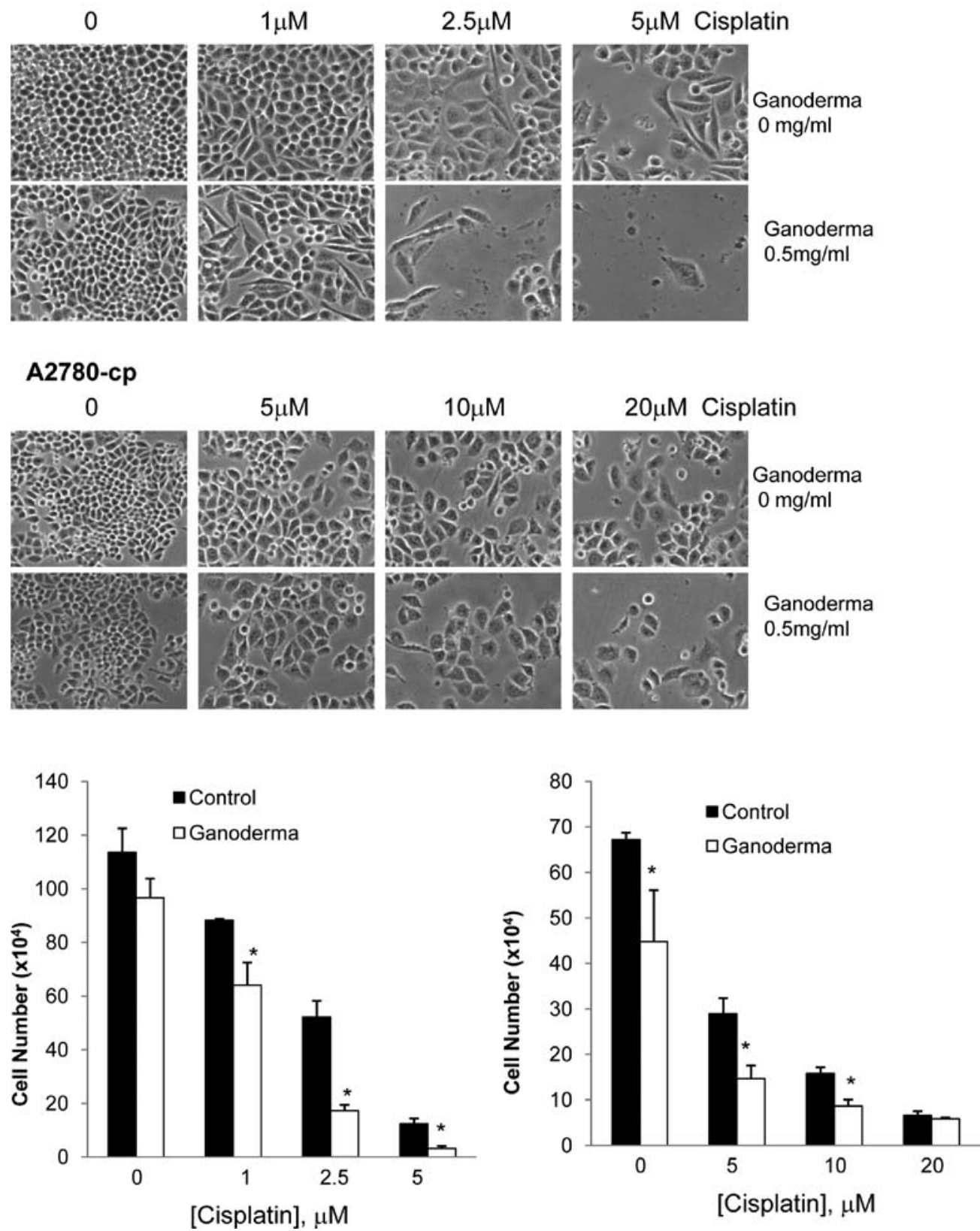

Figure 3. Ganoderma enhances the effect of cisplatin on inhibiting cell growth. A2780-s and A2780-cp cells were treated with the indicated concentrations of cisplatin in the absence or presence of $0.5 \mathrm{mg} / \mathrm{ml}$ Ganoderma. Cell morphology and cell numbers were determined at $48 \mathrm{~h}$ after treatment. Data represent the means \pm SEM $(n=4)$. ${ }^{*} \mathrm{P}<0.05$ vs. the corresponding control (without Ganoderma treatment).

expression and activation. In OV2008 and A2780-s cells, Ganoderma increased p53 and decreased total Akt levels (Fig. 7A). A slight inhibition of Akt activity was also observed with the high dose of Ganoderma (Fig. 7A). When OV2008 and $\mathrm{C}_{13} 3^{*}$ cells were treated with a combination of Ganoderma and cisplatin, a strong induction of p53 and an inhibition of Akt expression were observed (Fig. 7B).

\section{Discussion}

Ganoderma has been extensively used as a herbal medicine for the treatment of diseases, including cancer, for centuries in China, Japan and Korea (23). During the past decade, the anti-cancer effect of Ganoderma has also been widely tested in different cancer models in vivo and in vitro (24-26). In this study, we demonstrate that Ganoderma has potent anti-tumor effects on chemosensitive and chemoresistant ovarian cancer cells and we uncover potential mechanisms by which Ganoderma regulates cell proliferation, apoptosis and chemosensitivity. To the best of our knowledge, this is the first report of Ganoderma on ovarian cancer cells.

To test the effect of Ganoderma lucidum on ovarian cancer cells, we treated several EOC cell lines and a nontumorigenic IOSE cell line with Ganoderma and performed a varity of assays. Firstly, in cell viability/proliferation assays, we found that Ganoderma has potent cytotoxic effects on 
A.
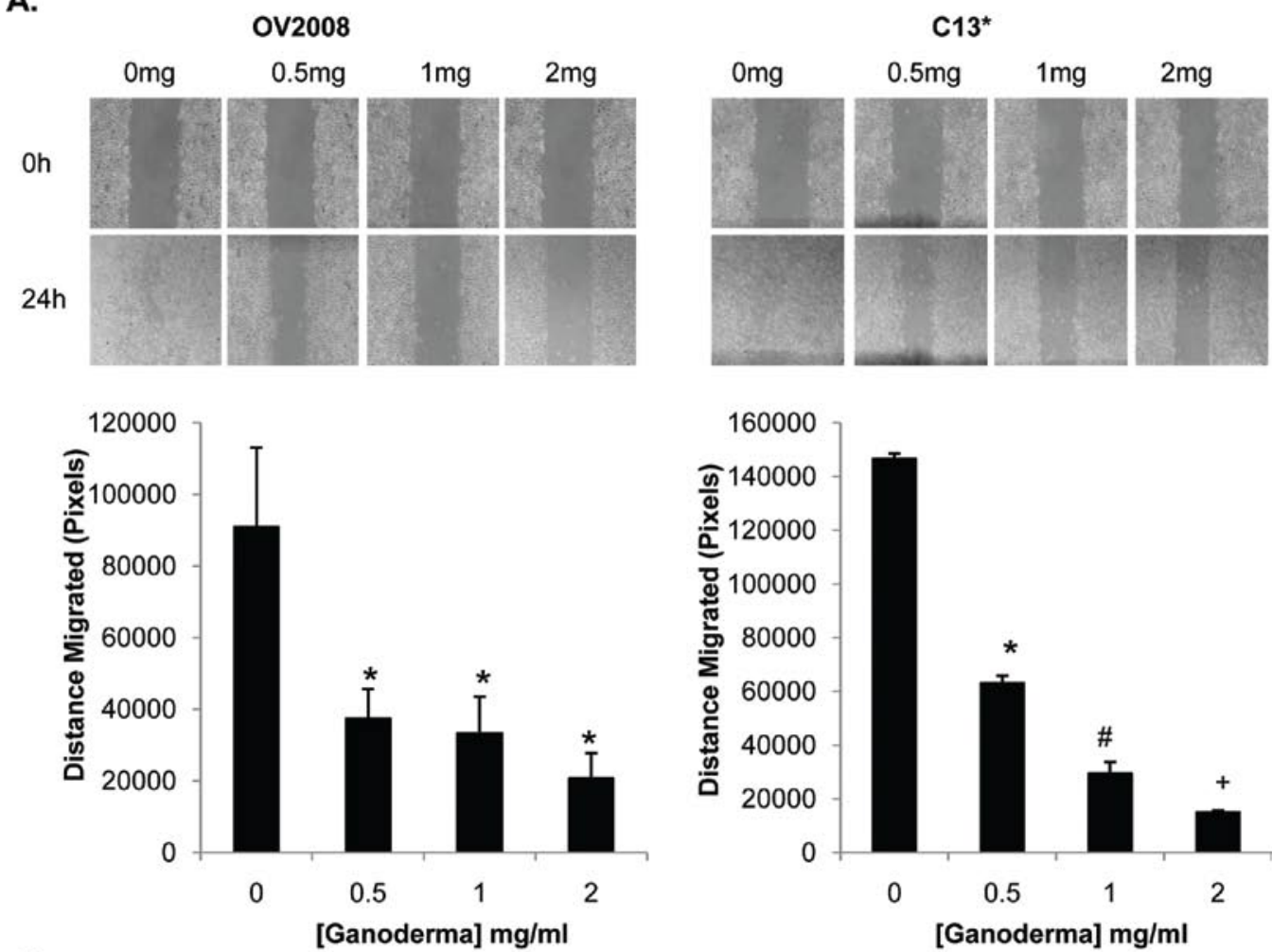

B.

0

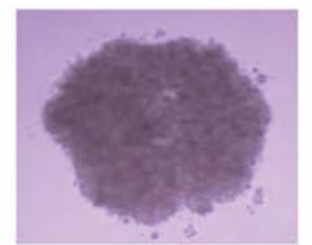

C.

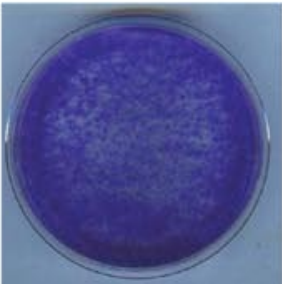

0.5
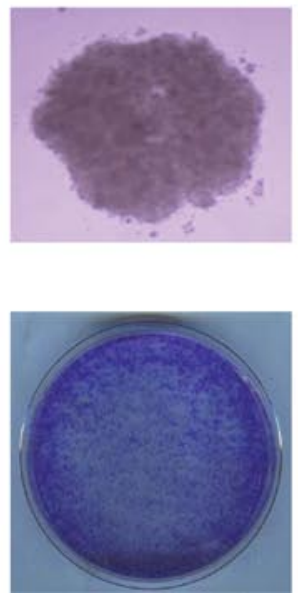
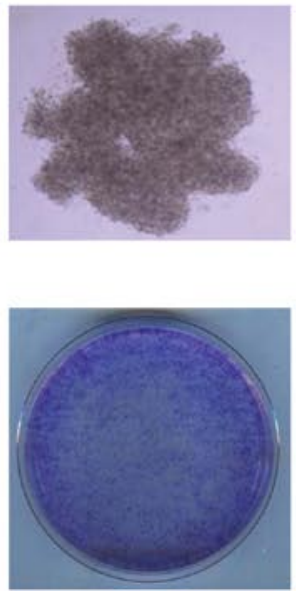

$2 \mathrm{mg} / \mathrm{ml}$
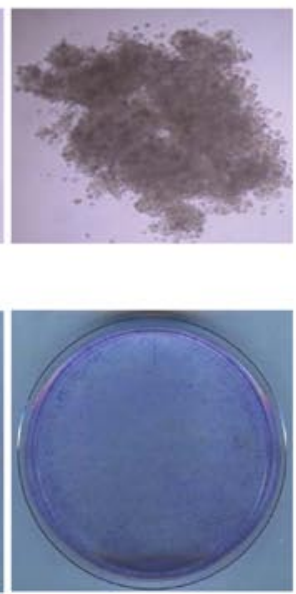

Figure 4. Ganoderma inhibits cell migration, spheroid formation and colony formation. (A) Wound healing assays. OV2008 and C13 ${ }^{*}$ cells were plated and a wound was created. Cells were then treated with different concentrations of Ganoderma for $24 \mathrm{~h}$. The distance between two sides of the wound was measured before and after treatment. A strong inhibition on migration was observed in the Ganoderma-treated cells (means $\pm \mathrm{SEM}, \mathrm{n}=3$ ). ${ }^{*} \mathrm{P}<0.05$ vs. no treatment, ${ }^{\#} \mathrm{p}<0.05 \mathrm{vs} .0 .5 \mathrm{mg} / \mathrm{ml}$ treatment, ${ }^{+} \mathrm{p}<0.05 \mathrm{vs} .1 \mathrm{mg} / \mathrm{ml}$ treatment. (B) Hanging drop culture showing the effect of Ganoderma on spheroid formation. (C) A representative colony formation assay performed in Skov3 cells. A strong dose-dependent inhibitory effect of Ganoderma on cells growth was observed.

EOC cells. However, such an effect was not prominent in normal ovarian epithelial cells, especially at a low dose, suggesting that malignant tumor cells are more sensitive to Ganoderma. This result is consistent with a recent study conducted on lung cancer cells showing that Ganoderma extracts are more cytotoxic in tumor cells than in normal cells (26). Secondly, using wound healing assays, we observed that Ganoderma treatment led to the attenuation of cell migration in a dose-dependent manner. The anti-migratory effect of
Ganoderma has been shown in many cancer cell lines $(27,28)$, suggesting its potency in reducing tumor invasiveness. Thirdly, Ganoderma markedly suppressed the spheroid aggregation. The control or low-dose Ganoderma lucidum-treated Skov3 cells formed very tight and compact globular spheroids, whereas the spheroids from the cells treated with higher concentrations of Ganoderma exhibited loose and irregular structures, indicating the strong efficacy of Ganoderma on ovarian cancer cell adhesion. Finally, Ganoderma remarkably 

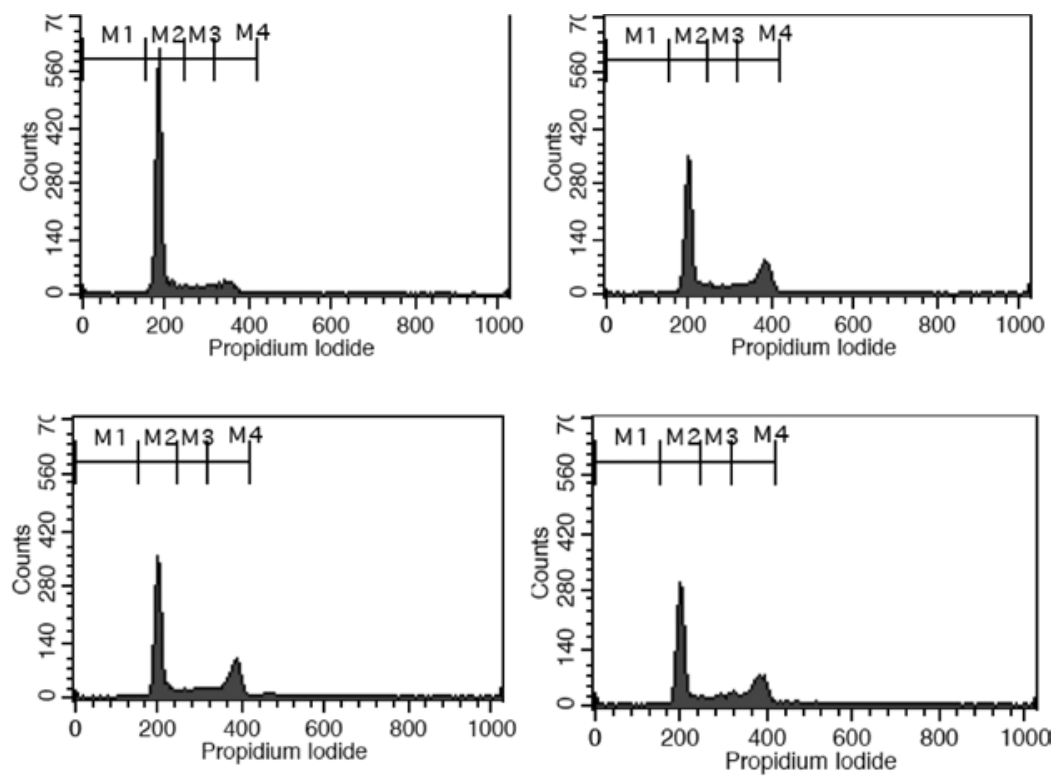

\begin{tabular}{|c|c|c|c|c|}
\hline & \multicolumn{4}{|c|}{ Ganoderma (mg/ml) } \\
\hline & 0 & 0.5 & 1 & 2 \\
\hline G1 & 75.82 & 53.32 & 50.95 & 48.27 \\
\hline S & 9.98 & 10.97 & 11.33 & 11.74 \\
\hline G2/M & 10.08 & 29.64 & 30.49 & 31.42 \\
\hline
\end{tabular}

Figure 5. Ganoderma blocked cell cycle progression at the G2/M phase. OV2008 cells were treated with or without Ganoderma and cell cycle profiles were analyzed by flow cytometry at $48 \mathrm{~h}$ after treatment.

A

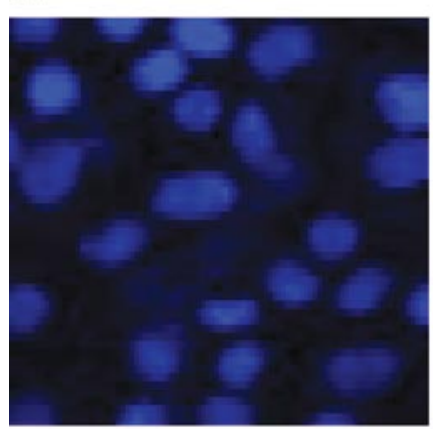

B

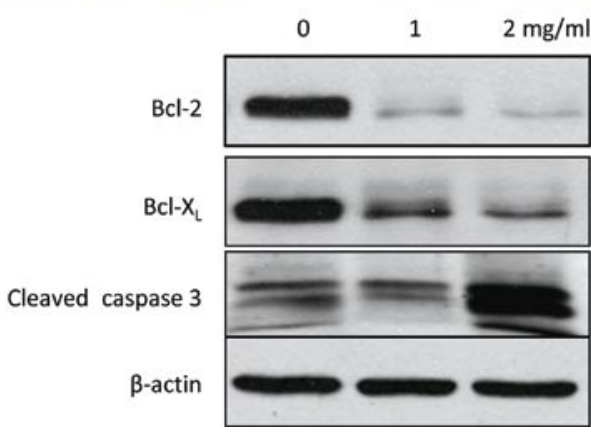

Figure 6. Ganoderma induced apoptosis. (A) OV2008 cells were treated with $1 \mathrm{mg} / \mathrm{ml}$ of Ganoderma for $48 \mathrm{~h}$, followed by Hoechst staining. Nuclei apoptotic features (DNA condensation and fragmentation, indicated by arrows) were observed in the Ganoderma-treated cells. (B) Western blot analysis of $\mathrm{Bcl}-2, \mathrm{Bcl}-\mathrm{X}_{\mathrm{L}}$ and cleaved caspase 3 in the control and Ganoderma-treated OV2008 cells. Equal protein loading was evaluated using anti- $\beta$-actin antibody. prevented the colony formation of Skov3 cells dose-dependently. A similar potency has been shown in breast cancer and myelogenous leukemia cells (29-31). Thus, our findings strongly suggest that Ganoderma has anti-tumor effects on ovarian cancer cells.

The inhibition of apoptosis, rather than enhanced cell proliferation, is considered to be a more important factor contributing to the development of cancer (32). Therefore, targeting apoptotic pathways and inducing apoptosis in tumor cells have been implied as critical mechanisms of anti-cancer agents. The anti-apoptotic Bcl-2 family members, Bcl-2 and Bcl- $\mathrm{x}_{\mathrm{L}}$, act as repressors of apoptosis by blocking the release of cytochrome-c, and the inhibition of caspase 3 activation (33). In this study, we observed that Ganoderma induced morphological changes in the cell nuclei which are characteristics of apoptosis, decreased Bcl-2 and Bcl- $\mathrm{x}_{\mathrm{L}}$ levels and activated caspase 3. These results indicate that Ganoderma induces apoptosis in EOC cells. The pro-apoptotic effect of Ganoderma has been well established in several other cancer cell lines, such as breast, prostate and lung cancer cells $(30,34,35)$.

It has been widely reported that Ganoderma lucidum extracts interfere with the cell cycle to act as anti-cancer agents. Ganoderma has been found to arrest the cell cycle at the $\mathrm{G} 2 / \mathrm{M}$ phase in several tumor cells, such as hepatoma, prostate cancer, myeloid leukemia and bladder cancer cells $(27,28,34,36)$. Consistent with these reports, we also observed an increase in G2/M cell population following Ganoderma treatment in ovarian cancer cells. p53 has been shown to regulate the $\mathrm{G} 2 / \mathrm{M}$ transition either through the induction of the downstream signaling cascade in the cytoplasm $(37,38)$ or 
A.

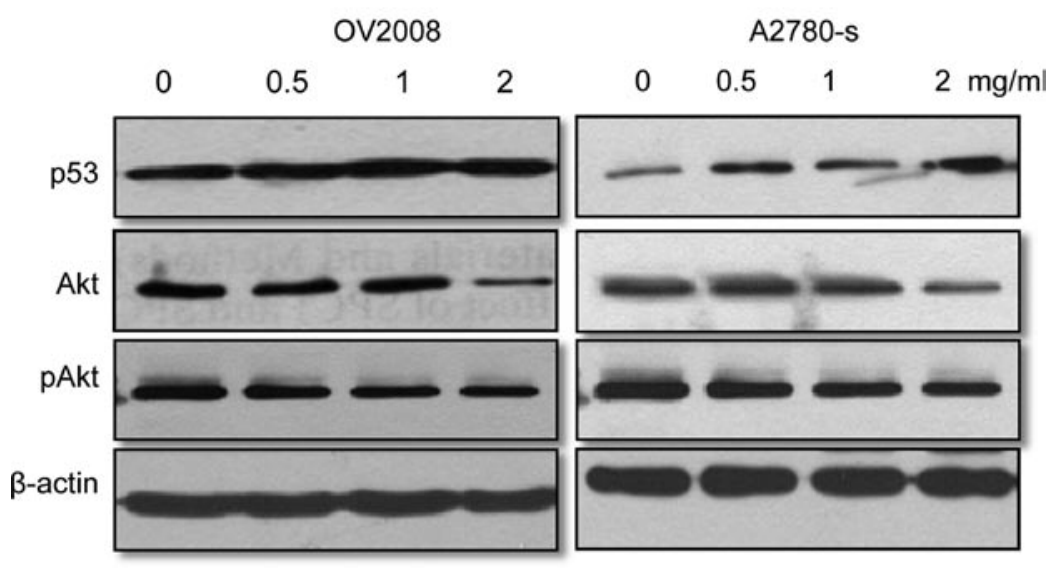

B.

OV2008

$\mathrm{C} 13^{*}$
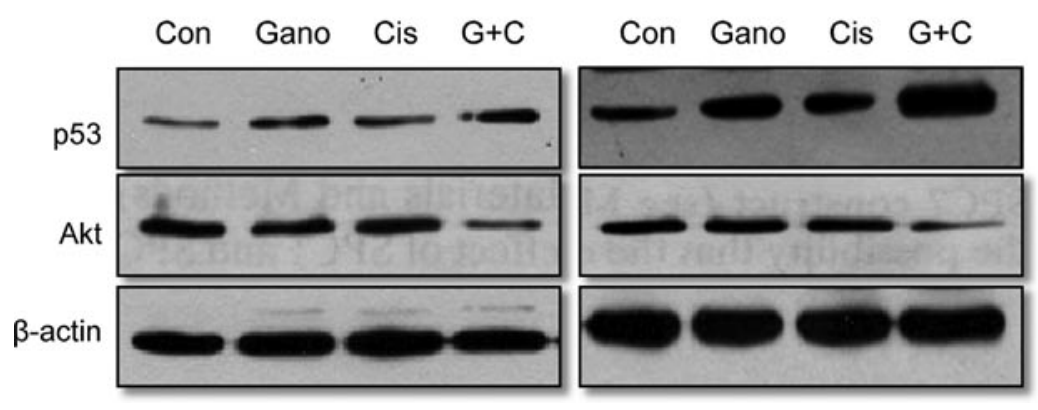

Figure 7. Ganoderma up-regulates p53 and down-regulates Akt. (A) OV2008 and A2780-s cells were treated with or without Ganoderma for 48 h. Protein lysates were blotted and probed by anti-p53, total Akt, phosphor-Akt (pAkt) and anti- $\beta$-actin antibodies. (B) OV2008 and C13* were treated with Ganoderma $(0.5 \mathrm{mg} / \mathrm{ml})$ and cisplatin $\left(2.5 \mu \mathrm{M}\right.$ for OV and $5 \mu \mathrm{M}$ for $\left.\mathrm{C} 13^{*}\right)$, alone or in combination, for $48 \mathrm{~h}$. Levels of $\mathrm{p} 53$ and total Akt were determined by Western blot analysis. Con, control; Gano, Ganoderma; Cis, cisplatin; G+C, Ganoderma plus cisplatin.

through the induction of apoptosis $(39,40)$. Our data also demonstrate that $\mathrm{p} 53$ protein expression is up-regulated after Ganoderma treatment. Thus, the G2/M cell cycle arrest is likely to be an outcome of p53 elevation.

The most interesting finding from this study is that Ganoderma sensitized the ovarian cancer cell response to cisplatin. Since we found that Ganoderma was effective in inhibiting cell growth, survival, migration and/or spheroid formation in several chemoresistant EOC cell lines, such as A2780-cp, C13* and Skov3, we tested whether Ganoderma could enhance the sensitivity of EOC cells to cisplatin. The Ganoderma treatment greatly potentiated the cisplatin effects in A2780s, a chemosensitive ovarian cancer cell line, as well as in its chemoresistant counterpart, the A2780cp cell line. Similar results were also observed in another pair of EOC cells, OV2008 and C13*. The Akt signaling pathway plays an important role in the control of cell survival. Many chemotherapeutic agents have been found to inhibit cancer cell growth and induce apoptosis through the inhibition of the Akt pathway (41). In EOC cells, it has been reported that Akt confers chemoresistance partly by inhibiting p53 activity $(42,43)$. We found that when a low dose of Ganoderma was combined with cisplatin, the Akt level was decreased while the p53 level was up-regulated. These findings suggest that Ganoderma modulates the sensitivity of EOC cells to cisplatin by regulating, at least in part, Akt and p53 expression.
Taken together, our results demonstrate that Ganoderma lucidum exerts multiple anti-tumor effects on ovarian cancer cells. We also provide evidence that Ganoderma enhances the chemosensitivity of EOC cells to cisplatin. Our findings suggest that Ganoderma lucidum could be useful in the treatment of chemosensitive and chemoresistant EOC.

\section{Acknowledgments}

This study was supported by a CIHR grant (MOP-89931) to C.P. S.Z. was supported by a visiting professorship from Hebei Province Government. C.P. is a recipient of a MidCareer Award from OWHC/CIHR.

\section{References}

1. Sanodiya BS, Thakur GS, Baghel RK, Prasad GB and Bisen PS: Ganoderma lucidum: a potent pharmacological macrofungus. Curr Pharm Biotechnol 10: 717-742, 2009.

2. Chen HS, Tsai YF, Lin S, et al: Studies on the immunomodulating and anti-tumor activities of Ganoderma lucidum (Reishi) polysaccharides. Bioorg Med Chem 12: 5595-5601, 2004.

3. Bao X, Liu C, Fang J and Li X: Structural and immunological studies of a major polysaccharide from spores of Ganoderma lucidum (Fr.) Karst. Carbohydr Res 332: 67-74, 2001.

4. Eo SK, Kim YS, Lee CK and Han SS: Possible mode of antiviral activity of acidic protein bound polysaccharide isolated from Ganoderma lucidum on herpes simplex viruses. JEthnopharmacol 72: 475-481, 2000. 
5. Li YQ and Wang SF: Anti-hepatitis B activities of ganoderic acid from Ganoderma lucidum. Biotechnol Lett 28: 837-841, 2006.

6. Li WJ, Nie SP, Chen Y, et al: Ganoderma atrum polysaccharide protects cardiomyocytes against anoxia/reoxygenation-induced oxidative stress by mitochondrial pathway. J Cell Biochem 110: 191-200, 2010

7. Kabir Y and Kimura S: Dietary mushrooms reduce blood pressure in spontaneously hypertensive rats (SHR). J Nutr Sci Vitaminol (Tokyo) 35: 91-94, 1989.

8. Kabir Y, Kimura S and Tamura T: Dietary effect of Ganoderma lucidum mushroom on blood pressure and lipid levels in spontaneously hypertensive rats (SHR). J Nutr Sci Vitaminol (Tokyo) 34: 433-438, 1988

9. Seto SW, Lam TY, Tam HL, et al: Novel hypoglycemic effects of Ganoderma lucidum water-extract in obese/diabetic $(+\mathrm{db} /+\mathrm{db})$ mice. Phytomedicine 16: 426-436, 2009.

10. Harhaji Trajkovic LM, Mijatovic SA, Maksimovic-Ivanic DD, et al: Anticancer properties of Ganoderma lucidum methanol extracts in vitro and in vivo. Nutr Cancer 61: 696-707, 2009.

11. Waterhouse DN: A novel combination of Chinese medicines to treat advanced cancers and lymphomas in rats. Chin Med 4: 22 , 2009.

12. Mahajna J, Dotan N, Zaidman BZ, Petrova RD and Wasser SP Pharmacological values of medicinal mushrooms for prostate cancer therapy: the case of Ganoderma lucidum. Nutr Cancer 61: 16-26, 2009.

13. Permuth-Wey J and Sellers TA: Epidemiology of ovarian cancer. Methods Mol Biol 472: 413-437, 2009.

14. Williams TI, Toups KL, Saggese DA, Kalli KR, Cliby WA and Muddiman DC: Epithelial ovarian cancer: disease etiology, treatment, detection, and investigational gene, metabolite, and protein biomarkers. J Proteome Res 6: 2936-2962, 2007.

15. Martin LP and Schilder RJ: Management of recurrent ovarian carcinoma: current status and future directions. Semin Oncol 36: 112-125, 2009

16. Xu G, Bernaudo S, Fu G, Lee DY, Yang BB and Peng C: Cyclin $\mathrm{G} 2$ is degraded through the ubiquitin-proteasome pathway and mediates the antiproliferative effect of activin receptor-like kinase 7. Mol Biol Cell 19: 4968-4979, 2008

17. Xu G, Zhong Y, Munir S, Yang BB, Tsang BK and Peng C: Nodal induces apoptosis and inhibits proliferation in human epithelial ovarian cancer cells via activin receptor-like kinase 7. J Clin Endocrinol Metab 89: 5523-5534, 2004.

18. Xu G, Zhou H, Wang Q, Auersperg N and Peng C: Activin receptor-like kinase 7 induces apoptosis through up-regulation of Bax and down-regulation of Xiap in normal and malignant ovarian epithelial cell lines. Mol Cancer Res 4: 235-246, 2006.

19. Xie Y, Li S, Yee A, et al: Ganoderma lucidum extract inhibits tumour cell proliferation and induces tumour cell death. Enzyme Microb Technol 40: 177-185, 2006.

20. Zietarska M, Maugard CM, Filali-Mouhim A, et al: Molecular description of a 3D in vitro model for the study of epithelial ovarian cancer (EOC). Mol Carcinog 46: 872-885, 2007.

21. Franken NA, Rodermond HM, Stap J, Haveman J and van Bree C: Clonogenic assay of cells in vitro. Nat Protoc 1: 2315-2319, 2006

22. Tsang WP, Chau SP, Fung KP, Kong SK and Kwok TT: Modulation of multidrug resistance-associated protein 1 (MRP1) by p53 mutant in Saos-2 cells. Cancer Chemother Pharmacol 51: 161-166, 2003

23. Yuen JW and Gohel MD: Anticancer effects of Ganoderma lucidum: a review of scientific evidence. Nutr Cancer 53: 11-17, 2005.

24. Weng CJ, Chau CF, Yen GC, Liao JW, Chen DH and Chen KD: Inhibitory effects of Ganoderma lucidum on tumorigenesis and metastasis of human hepatoma cells in cells and animal models. J Agric Food Chem 57: 5049-5057, 2009.
25. Hsu SC, Ou CC, Chuang TC, et al: Ganoderma tsugae extract inhibits expression of epidermal growth factor receptor and angiogenesis in human epidermoid carcinoma cells: In vitro and in vivo. Cancer Lett 281: 108-116, 2009.

26. Sadava D, Still DW, Mudry RR and Kane SE: Effect of Ganoderma on drug-sensitive and multidrug-resistant small-cell lung carcinoma cells. Cancer Lett 277: 182-189, 2009.

27. Muller CI, Kumagai T, O'Kelly J, Seeram NP, Heber D and Koeffler HP: Ganoderma lucidum causes apoptosis in leukemia, lymphoma and multiple myeloma cells. Leuk Res 30: 841-848, 2006.

28. Lu QY, Jin YS, Zhang Q, et al: Ganoderma lucidum extracts inhibit growth and induce actin polymerization in bladder cancer cells in vitro. Cancer Lett 216: 9-20, 2004.

29. Chui CH, Wong RS, Cheng GY, et al: Antiproliferative ability of a combination regimen of crocodile egg extract, wild radix ginseng and natural Ganoderma lucidum on acute myelogenous leukemia. Oncol Rep 16: 1313-1316, 2006.

30. Jiang J, Grieb B, Thyagarajan A and Sliva D: Ganoderic acids suppress growth and invasive behavior of breast cancer cells by modulating AP-1 and NF- $\mathrm{KB}$ signaling. Int $\mathrm{J}$ Mol Med 21: 577-584, 2008.

31. Thyagarajan A, Zhu J and Sliva D: Combined effect of green tea and Ganoderma lucidum on invasive behavior of breast cancer cells. Int J Oncol 30: 963-969, 2007.

32. Westphal S and Kalthoff H: Apoptosis: targets in pancreatic cancer. Mol Cancer 2: 6, 2003.

33. Ghobrial IM, Witzig TE and Adjei AA: Targeting apoptosis pathways in cancer therapy. CA Cancer J Clin 55: 178-194, 2005.

34. Jiang J, Slivova V, Valachovicova T, Harvey K and Sliva D: Ganoderma lucidum inhibits proliferation and induces apoptosis in human prostate cancer cells PC-3. Int J Oncol 24: 1093-1099, 2004.

35. Tang W, Liu JW, Zhao WM, Wei DZ and Zhong JJ: Ganoderic acid T from Ganoderma lucidum mycelia induces mitochondria mediated apoptosis in lung cancer cells. Life Sci 80: 205-211, 2006.

36. Lin SB, Li CH, Lee SS and Kan LS: Triterpene-enriched extracts from Ganoderma lucidum inhibit growth of hepatoma cells via suppressing protein kinase $\mathrm{C}$, activating mitogen-activated protein kinases and G2-phase cell cycle arrest. Life Sci 72: 2381-2390, 2003.

37. Hermeking $\mathrm{H}$, Lengauer $\mathrm{C}$, Polyak $\mathrm{K}$, et al: 14-3-3 sigma is a p53-regulated inhibitor of G2/M progression. Mol Cell 1: 3-11, 1997.

38. Bunz F, Dutriaux A, Lengauer C, et al: Requirement for $\mathrm{p} 53$ and p21 to sustain G2 arrest after DNA damage. Science 282: 1497-1501, 1998

39. Yonish-Rouach E, Resnitzky D, Lotem J, Sachs L, Kimchi A and Oren M: Wild-type p53 induces apoptosis of myeloid leukaemic cells that is inhibited by interleukin-6. Nature 352: 345-347, 1991.

40. Shaw P, Bovey R, Tardy S, Sahli R, Sordat B and Costa J: Induction of apoptosis by wild-type p53 in a human colon tumor-derived cell line. Proc Natl Acad Sci USA 89: 4495-4499, 1992.

41. Aggarwal BB and Shishodia S: Molecular targets of dietary agents for prevention and therapy of cancer. Biochem Pharmacol 71: $1397-1421,2006$

42. Yang X, Fraser M, Abedini MR, Bai T and Tsang BK: Regulation of apoptosis-inducing factor-mediated, cisplatin-induced apoptosis by Akt. Br J Cancer 98: 803-808, 2008.

43. Yang X, Fraser M, Moll UM, Basak A and Tsang BK: Akt-mediated cisplatin resistance in ovarian cancer: modulation of p53 action on caspase-dependent mitochondrial death pathway. Cancer Res 66: 3126-3136, 2006. 